\title{
PEMANFAATAN E-LEARNING SEBAGAI ALTERNATIF PENGGANTI PELATIHAN TATAP MUKA BAGI PENDIDIK DAN TENAGA KEPENDIDIKAN PENDIDIKAN NONFORMAL
}

\author{
Putu Ashintya Widhiartha*
}

\begin{abstract}
Recently, there have been massive efforts in E-learning implementation for educator training around the world. E-learning could shortly be defined as a web-based educational system on platform with Internet, Intranet or computer access. This article describes the possibility to implement E-learning for non-formal teacher training in Indonesia. Non-formal teachers have to realize that they face new challenge to improve their competencies and must be able to make appropriate use of Information and Communication Technologies (ICT). This is a challenge that has caused non-formal teachers to reflect on how they adapt to new educational changes without compromising the quality of education. In addition E-learning also could be used to reduce the enormous cost of conventional non-formal teacher training.
\end{abstract}

Keywords : e-learning, online training, web-based learning

\begin{abstract}
Abstrak
Baru-baru ini, telah terjadi upaya besar-besaran dalam implementasi E-learning untuk pelatihan pendidik di seluruh dunia. E-learning bisa didefinisikan sebagai web sistem pendidikan berbasis pada platform dengan Internet, Intranet atau mengakses komputer. Artikel ini menjelaskan kemungkinan untuk mengimplementasikan E-learning untuk pelatihan guru non-formal di Indonesia. Guru non-formal menyadari bahwa mereka harus menghadapi tantangan baru untuk meningkatkan kompetensi mereka dan harus dapat menggunakan Teknologi Informasi dan Komunikasi (ICT) dengan tepat . Ini adalah tantangan yang telah menyebabkan guru non-formal untuk memikirkan bagaimana mereka beradaptasi dengan perubahan-perubahan pendidikan baru tanpa mengorbankan kualitas pendidikan. Selain itu E-learning juga dapat digunakan untuk mengurangi biaya besar konvensional pelatihan guru nonformal .
\end{abstract}

Kata-kata kunci: e-learning, pelatihan online, belajar berbasis web

\section{PENDAHULUAN}

Pola peningkatan kompetensi bagi pendidik dan tenaga kependidikan pendidikan nonformal (PTK PNF) selama ini lebih ditekankan menggunakan pelatihan tatap muka. Pada umumnya pelatihan dilaksanakan oleh lembaga-lembaga penyedia pelatihan dengan mengundang para peserta yang berasal dari berbagai daerah di masing-masing area kerjanya. Pembiayaan pelatihan umumnya berasal dari APBN atau APBD dan merupakan salah satu jenis program yang menelan biaya terbesar. Sebagai contoh pada tahun $2008 \mathrm{di}$ BPPNFI Regional IV Surabaya, untuk sebuah pelatihan tingkat provinsi Jawa Timur dengan mengundang 30

\footnotetext{
* Pamong Belajar pada BPPNFI Regional IV Surabaya
}

orang peserta selama satu minggu dibutuhkan dana sekitar seratus limapuluh juta rupiah. Besaran terbesar dari dana tersebut adalah pada komponen akomodasi peserta yang meliputi biaya penginapan dan konsumsi. Sedangkan untuk komponen pembelajaran sendiri ternyata masih di bawah biaya akomodasi. Hal ini patut disayangkan karena apabila biaya akomodasi tersebut dikonversi menjadi biaya pembelajaran dapat meningkatkan jumlah peserta yang terlayani secara signifikan sesuai misi perluasan akses terhadap peningkatan mutu PTK PNF.

Saat ini telah terjadi peningkatan penggunaan internet untuk pembelajaran (E-learning) di berbagai satu- 
an pendidikan di Indonesia. Berbagai perguruan tinggi dan lembaga pelatihan swasta telah menerapkan $E$ learning dalam meningkatkan layanan mereka kepada peserta didik secara masif dalam beberapa tahun terakhir. Peserta didik yang berada di luar kota tidak perlu harus datang pada setiap kuliah, materi kuliah dapat diunduh dari situs yang tersedia. Diskusi dan kuliah dengan pendidik dapat dilakukan melalui surat elektronik, discussion board, messenger, bahkan secara real time dengan fasilitas video conference.

Lima tahun yang lalu isu kualitas jaringan internet dan minimnya ketersediaan konten edukasi berbahasa Indonesia adalah salah satu penghalang bagi penggunaan E-learning. Saat ini kualitas jaringan internet di Indonesia semakin baik dan berkat peran serta aktif para pelaku Teknologi Informasi dan Komunikasi (TIK) di Indonesia telah lahir berbagai situs yang menyediakan referensi dan bahan belajar berbahasa Indonesia. Situs-situs tersebut memberikan sumbangan besar pada pemanfaatan internet di sistem pendidikan Indonesia karena keberadaannya membuat para pemakai internet bisa melakukan akses terhadap berbagai referensi dan bahan belajar yang mereka butuhkan. Beberapa contoh situs semacam itu adalah www.ilmukomputer.com yang dikembangkan oleh Romi Satrio Wahono seorang peneliti LIPI dan www.edukasi.net yang dikembangkan oleh PUSTEKKOM DEPDIKNAS. Situs-situs E-learning pada umumnya menyediakan fasilitas di mana para anggotanya dapat melakukan upload tulisan atau bahan belajar di internet untuk diakses dari seluruh penjuru dunia. Keuntungan yang didapat oleh sang penulis sendiri bukanlah keuntungan secara finansial tetapi pengakuan secara intelektual.

Tulisan berikut ini adalah sebuah studi pustaka tentang E-learning dan dilengkapi dengan berbagai laporan tentang keberhasilan penggunaan E-learning dalam pelatihan tenaga pendidik baik di dalam maupun luar negeri. Dengan tulisan ini penulis berharap berbagai pemangku kebijakan peningkatan mutu PTK PNF dapat memahami dan menjadikan E-learning sebagai salah satu alternatif pengganti pelatihan tatap muka.

\section{PEMBAHASAN}

\section{Definisi E-learning}

Pada paradigma tradisional proses belajar mengajar pada umumnya berlangsung di ruang kelas dan ditandai dengan kehadiran pendidik di muka kelas. Pendidik memiliki tanggungjawab penuh terhadap jalannya proses belajar mengajar dan bisa dianggap sebagai sumberdaya paling penting dari sebuah proses belajar mengajar. Sebaliknya pada paradigma baru, peserta didik harus difasilitasi sesuai kebutuhannya masing-masing. Setiap peserta didik adalah spesifik dan memiliki kebutuhan belajar yang berbeda-beda. Proses belajar mengajar harus berfokus pada aktifitas "belajar" dan bukan pada aktifitas "mengajar" seperti pada paradigma lama. Keberadaan pendidik bisa digantikan oleh bahan belajar berupa modul, diktat, perangkat lunak edukasi yang bisa digunakan untuk belajar secara mandiri oleh peserta didik.

Paradigma baru yang menjadikan peserta didik sebagai active learner tersebut saat ini mendapatkan sarana yang sesuai untuk diimplementasikan pada sistem pendidikan di Indonesia dengan keberadaan Teknologi Informasi dan Komunikasi (TIK). TIK mampu berperan dalam menghasilkan berbagai produk bahan belajar yang jauh lebih menarik untuk dipelajari, memiliki unsur interaktif yang tinggi, dan mudah dipahami oleh peserta didik. Segala kelebihan tersebut dapat mempercepat proses belajar mereka. Lebih dari itu, TIK juga mampu mengantarkan berbagai bahan belajar tersebut ke hadapan peserta didik tanpa batasan jarak dan waktu dengan adanya internet sebagai medianya. Dengan adanya TIK maka telah muncul berbagai model pembelajaran baru dalam dua dekade terakhir. Menurut Mayer (2001) dan Wahono (2003) beberapa contoh model tersebut, antara lain.

1. Computer Based Learning/Training (CBL/CBT)

Model CBL/CBT berkembang sekitar pertengahan tahun 1990-an. Saat itu berbagai pelatihan atau kelas menyediakan berbagai bahan belajar berupa modul elektronik baik berupa perangkat lunak edukasi maupun softcopy dari berbagai modul cetak yang sudah ada sebelumnya. Bentuk ini di kemudian hari dikenal sebagai e-book dan berkembang semakin pesat berkat adanya format file pdf dari Adobe.

Pada era tersebut CBL/CBT sendiri berkembang pada komputer stand-alone dan belum terhubung dengan internet. Biasanya pembelajaran dengan model $C B L / C B T$ adalah untuk penyiapan tenaga ahli pada suatu bidang yang memerlukan pelatihan terlebih dahulu sebelum menempati posisinya. Perangkat lunak simulasi membantu peserta didik melakukan simulasi atas pekerjaan yang hendak dilakukan. Dengan simulasi maka proses belajar menjadi lebih mudah dan biaya pun bisa ditekan lebih murah dibandingkan apabila mereka harus mempraktikkan sendiri pada 
peralatan yang sebenarnya. Modul elektronik mempermudah peserta untuk mempelajari secara mandiri materi yang harus dipelajari dan tidak memerlukan biaya cetak yang tinggi.

\section{Web-based Learning}

Dengan semakin luasnya perkembangan internet maka perkembangan selanjutnya adalah terjadinya perluasan akses terhadap bahan-bahan belajar CBL/ $C B T$ di atas. Berbagai perangkat lunak edukasi ataupun softcopy dari modul, diktat, dan berbagai buku elektronik (e-book) lainnya yang semula didistribusikan dalam bentuk disket atau CD mulai membanjiri internet. Dengan melakukan upload berbagai referensi dan bahan belajar di internet berarti membuka akses dari seluruh penjuru dunia terhadap berbagai bahan belajar tersebut. Para pengguna internet pun bisa mempelajari apa saja dari berbagai situs web yang tersedia.

Demikian pula para penyelenggara pendidikan mulai memanfaatkan internet untuk memperluas layanan mereka pada siapapun yang ingin menjadi peserta didiknya. Berbagai kelas dan pelatihan bisa diikuti hanya dengan melakukan berbagai download terhadap bahan belajar elektronik, berdiskusi dengan dosen melalui email atau forum-forum diskusi online, dan mengikuti ujian secara online di internet. Setelah lulus sang peserta didik tinggal menunggu ijazah atau sertifikat yang terkirim ke alamatnya. Model inilah yang dikenal sebagai Web-based learning, sebuah model pembelajaran jarak jauh (distance learning) yang menggunakan internet sebagai sarananya.

\section{Mobile Learning}

TIK tidak hanya terbatas pada penggunaan komputer saja. Berbagai model pembelajaran yang menggunakan peralatan TIK lainnya seperti misalnya telepon genggam pun saat ini telah mulai berkembang. Dengan berbagai fitur dan teknologi yang dimiliki telepon genggam saat ini telah melahirkan sebuah model pembelajaran baru yang dikenal sebagai mobile learning (m-learning). Aktifitas utama pada M-learning adalah mendistribusikan bahan belajar kepada peserta didik agar dapat diakses menggunakan perangkat komunikasi portabel semacam telepon genggam atau smart phone.

Berbagai bentuk model pembelajaran dengan berbasiskan TIK seperti tersebut di atas itulah yang dikatergorikan sebagai bagian dari pembelajaran secara elektronik atau lebih dikenal sebagai E-learning. Tidak mudah untuk mendefinisikan E-learning karena begitu banyaknya pendapat yang beredar, beberapa di antaranya antara lain adalah:

Menurut Henderson (2003) :

1. E-learning adalah belajar pada jarak yang mengguna- kan teknologi komputer (biasanya Internet).

2. E-learning memungkinkan karyawan untuk belajar komputer kerja mereka tanpa bepergian ke kelas.

3. E-learning dapat menjadi dijadwalkan sesi dengan instruktur dan siswa lain, atau dapat sesuai permintaan karyawan saja yang dapat mengambil untuk belajar secara mandiri pada saat itu lebih mudah.

Menurut Khan (2005) dalam Adri (2008), elearning dapat dilihat sebagai sebuah pendekatan inovatif untuk memberikan welldesign, berpusat pada peserta didik, interaktif, dan memfasilitasi lingkungan belajar kepada siapa pun, di mana pun, kapan saja dengan memanfaatkan sifat-sifat dan sumber daya dari berbagai teknologi digital bersama dengan bentuk lain cocok untuk bahan pembelajaranr terbuka, fleksibel dan didistribusikan lingkungan belajar

Hartley (2001) dalam Wahono (2003) menjelaskan e-learning merupakan suatu jenis belajar mengajar yang memungkinkan tersampaikannya bahan ajar ke siswa dengan menggunakan media internet, intranet atau media jaringan komputer lain.

Sering terdapat perdebatan apakah penggunaan istilah E-learning untuk pembelajaran yang menggunakan TIK justru mengingkari penggunaan huruf e di depan kata learning tersebut yang berasal dari kata "electronic". Hal ini mengingat banyak perangkat elektronik lain yang secara kelompok bukan merupakan sarana TIK semacam televisi, radio, dan VCD/DVD juga banyak digunakan sebagai sarana pembelajaran. Tanpa menafikan media elektronik lainnya semacam televisi dan radio, terminologi $E$-learning bisa dikatakan telah identik dengan TIK. Sementara pembelajaran dengan menggunakan media semacam video dan televisi lebih sesuai mengacu pada istilah multimedia learning. Perdebatan lainnya adalah apakah yang disebut sebagai E-learning harus selalu mengacu pada pembelajaran dengan internet (Nugraha, 2007).

\section{Kategori E-learning}

Seperti halnya definisi, pengkategorian e-learning pun tidak bisa dilakukan dengan mudah mengingat banyaknya pendapat akan aspek yang mendasari kategorisasi E-learning. Pada tulisan ini ada dua kategorisasi yang digunakan, yaitu tipe E-learning berdasarkan interaksi dengan sistem dan kategorisasi dengan framework 4-tier Model dari IBM.

a. Interaksi antara Sistem dan Manusia

Ditinjau dari segi interaksi antara sistem dengan manusia maka ada tiga kategori dasar dari E-learning (Henderson, 2003), yaitu synchronous learning, selfdirected learning, dan asynchronous (collaborative) learning. 
Masing-masing kategori tersebut pada dasarnya mengacu pada bagaimana perasaan seorang peserta didik pada saat melakukan proses pembelajaran dengan sistem e-learning. Perasaan tersebut dapat berupa perasaan terisolasi, atau menjadi bagian dari sebuah kelompok. Apabila menjadi bagian dari sebuah kelompok bagaimanakah komunikasi dan interaksi yang terjadi pada kelompok tersebut.

\section{Synchronous Learning}

Pada pembelajaran synchronous, kondisinya mirip dengan pembelajaran konvensional hanya saja pada E-learning hal ini tidak ditandai dengan kehadiran secara fisik. Pada bentuk synchronous ini pendidik (instruktur), peserta didik dan rekan-rekannya melakukan "pertemuan" secara online di internet. Melakukan proses belajar mengajar seolah sedang berada pada ruang fisik yang sama.

\section{Self-directed Learning}

Pada kategori ini peserta didik melakukan pembelajaran secara mandiri dengan mengakses berbagai referensi dan bahan belajar yang disediakan. Tidak ada instruktur ataupun waktu khusus untuk berdiskusi dengan sesama peserta didik. Masingmasing peserta didik melakukan proses belajar sesuai dengan kebutuhannya.

\section{Asynchronous (Collaborative) Learning}

Kategori ini mengkombinasikan karakteristik dari kedua kategori sebelumnya. Peserta didik belajar secara mandiri namun tetap berkomunikasi dengan peserta didik lainnya maupun dengan pendidik walaupun tidak harus di waktu khusus. Penggunaan email, instant message (Yahoo! Messenger, Gtalk) ataupun board pada forum dapat digunakan sebagai media komunikasi dan interaksi baik dengan pendidik maupun sesama peserta didik.

Tidak ada bentuk yang sempurna karena ketiganya cocok untuk berbagai situasi yang berbeda. Tabel 1 berikut ini akan menjelaskan secara lebih detail tentang karakteristik, kelebihan, dan kelemahan dari masing-masing kategori E-learning di atas

Tabel 1. Karakteristik Masing-masing Kategori E-learning

\begin{tabular}{|c|c|c|c|c|c|c|c|}
\hline No. & Kategori & \multicolumn{2}{|r|}{ Ciri } & \multicolumn{2}{|r|}{ Kelebihan } & \multicolumn{2}{|r|}{ Kelemahan } \\
\hline 1 & Synchronous & $\begin{array}{l}\square \\
\square \\
\square\end{array}$ & $\begin{array}{l}\text { Dipandu } \\
\text { instruktur } \\
\text { Terjadwal } \\
\text { Kolaboratif }\end{array}$ & $\square$ & $\begin{array}{l}\text { Familiar bagi peserta didik } \\
\text { karena mirip dengan } \\
\text { pembelajaran konvensional } \\
\text { Adanya komunikasi antara } \\
\text { peserta didik } \\
\text { Keberadaan pendidik } \\
\text { menjadikan proses belajar } \\
\text { menjadi lebih terjamin }\end{array}$ & $\begin{array}{l}\square \\
\square\end{array}$ & $\begin{array}{l}\text { Memerlukan waktu } \\
\text { khusus } \\
\text { Ada biaya untuk } \\
\text { instruktur } \\
\text { Memerlukan bandwidth } \\
\text { dan kecepatan internet } \\
\text { yang memadai dan } \\
\text { setara untuk semua } \\
\text { peserta didik. }\end{array}$ \\
\hline 2 & Self-directed & $\begin{array}{l}\square \\
\square\end{array}$ & $\begin{array}{l}\text { Peserta didik } \\
\text { belajar secara } \\
\text { mandiri } \\
\text { Tidak terjadwal }\end{array}$ & $\begin{array}{l}\square \\
\square\end{array}$ & $\begin{array}{l}\text { On demand (proses belajar } \\
\text { dapat dilakukan kapanpun) } \\
\text { Sesuai untuk peserta didik } \\
\text { yang memiliki rasa ingin tahu } \\
\text { besar dan aktif mencari } \\
\text { sumber belajar }\end{array}$ & $\square$ & $\begin{array}{l}\text { Tidak adanya pendidik } \\
\text { sebagai penjamin } \\
\text { kualitas proses belajar } \\
\text { Tidak cocok untuk } \\
\text { peserta didik yang } \\
\text { menyukai belajar secara } \\
\text { berkelompok }\end{array}$ \\
\hline 3 & $\begin{array}{c}\text { Asynchronou } \\
\text { s }\end{array}$ & $\begin{array}{l}\square \\
\square \\
\square\end{array}$ & $\begin{array}{l}\text { Dipandu oleh } \\
\text { instruktur } \\
\text { Tidak terdjadwal } \\
\text { sepenuhnya, } \\
\text { sesama peserta } \\
\text { didik dapat } \\
\text { "bertemu" tetapi } \\
\text { tidak dalam } \\
\text { yang sama. } \\
\text { Kolaboratif }\end{array}$ & $\square$ & $\begin{array}{l}\text { Adanya instruktur } \\
\text { menjamin kualitas dari } \\
\text { proses pembelajaran. } \\
\text { Peserta didik dapat } \\
\text { menentukan sendiri } \\
\text { kebutuhan belajarnya dan } \\
\text { referensi untuk memenuhi } \\
\text { kebutuhan tersebut. } \\
\begin{array}{l}\text { Masih memungkinkan } \\
\text { pembelajaran } \\
\text { kolaboratif. }\end{array}\end{array}$ & $\square$ & $\begin{array}{l}\text { Tidak mendukung } \\
\text { komunikasi dengan } \\
\text { cepat karena tidak } \\
\text { adanya jadwal khusus }\end{array}$ \\
\hline
\end{tabular}

\section{b. IBM 4-Tier Learning Model}

IBM 4-Tier Learning Model adalah sebuah framework untuk penerapan E-learning di dalam organisasi. IBM sebagai salah satu perusahaan terbesar dan tertua pada bidang teknologi informasi menerapkan framework ini pada sistem pelatihan staf di internal perusahaan. Framework ini berpedoman bahwa sistem E-learning membutuhkan berbagai pendekatan untuk situasi yang berbeda. Satu bentuk tidak akan selalu cocok untuk berbagai situasi. Pada dasarnya IBM 4- 
Tier Model adalah kategorisasi cara belajar yang terdiri dari empat tingkatan (Henderson,2003), yaitu:

1. Learn from information

Pada tier ini seorang peserta didik belajar secara mandiri (self-directed) menggunakan berbagai bahan belajar yang sesuai untuk kebutuhannya. Tier ini sesuai untuk proses belajar mengajar yang peserta didiknya mampu melakukan konstruksi sendiri atas pengetahuan yang dipelajarinya tanpa bantuan dari sesama peserta didik maupun instruktur.

\section{Learn from interaction}

Pada tier ini peserta didik belajar secara mandiri dari berbagai bahan belajar yang sesuai dengan kebutuhannya. Berbeda dengan tier sebelumnya, pada tier ini peserta didik juga berinteraksi secara aktif dengan bahan belajar tersebut. Tier ini lebih banyak diterapkan pada proses pembelajaran yang bersifat simulatif di mana peserta didik dituntut untuk selalu "berkomunikasi" dengan bahan belajar.

\section{Learn from Collaboration}

Pada tier ini peserta didik menggunakan elearning secara bersama dan terhubung secara online dengan peserta didik lainnya serta instruktur via jaringan atau internet. Berbagai media yang bisa digunakan semacam chat room, email dan instant message digunakan sebagai alat berkomunikasi. Para peserta didik dapat "bertemu" pada waktu yang sama (synchronous) atau meninggalkan pesan dan topik pembicaraan pada berbagai forum diskusi online dan mendapatkan respon dari peserta didik yang lain atau instruktur beberapa saat kemudian.

\section{Learn from Colocation}

Tier ini sama dengan pembelajaran konvensional di mana peserta didik bertemu satu dengan lainnya pada waktu dan ruang kelas yang sama. Para pendesain IBM 4 Tier Model meyakini bahwa tier khusus untuk pembelajaran konvensional harus tetap ada. Hal ini didasari opini bahwa teknologi tidak akan pernah mengubah beberapa aspek pokok dari proses pembelajaran semacam pengalaman berdiskusi dengan sesama peserta didik dan pendidik, komunikasi non-verbal, dan adaptasi yang lebih mudah dengan pembelajaran konvensional. Untuk lebih memahami keempat tier tersebut dapat diamati pada gambar 1 berikut ini (Henderson, 2003):
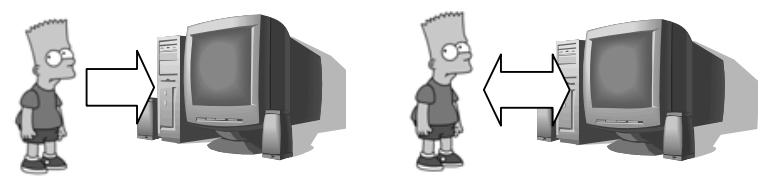

1. Learn from Information

2. Learn from Interaction

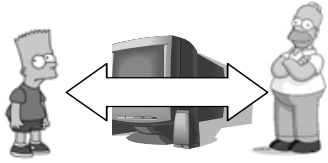

3. Learn from Collaboration

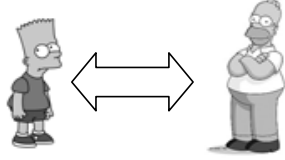

4. Learn from Colocation
Gambar 1. Cara belajar pada 4 tier learning model

Beberapa situasi proses belajar mungkin bisa dilakukan oleh diri sendiri. Sebaliknya proses belajar yang lain membutuhkan kerjasama antar peserta didik terutama dalam berdiskusi mencari solusi dari suatu permasalahan. Karakteristik lain adalah kadangkala diperlukan kombinasi antar e-learning dengan berbagai bentuk pembelajaran konvensional, hal inilah yang dikenal sebagai blended learning (Wahono, 2007).

\section{Membangun E-learning}

Menurut Henderson (2003) ada beberapa langkah yang bisa dilakukan untuk membangun sebuah sistem E-learning:

1. Menentukan Tujuan dari Sistem E-learning

Pada tahap ini pengembang sistem harus menentukan apa yang ingin dicapai dengan adanya $E$ learning tersebut. Tahap ini biasanya dengan mudah dilupakan akibat antusiasme berlebihan dari pengembang sistem E-learning. Pada akhirnya $E$ learning tersebut tidak akan sesuai dengan kebutuhan calon pengguna dan tidak memberikan hasil yang diharapkan.

2. Memulai Sistem dalam Skala Kecil

Beberapa pengembang memilih untuk memulai sistem E-learning langsung pada skala besar. Hal kurang baik ditinjau dari segi manajemen resiko karena proyek dalam skala besar juga memiliki resiko kegagalan yang besar pula. Sebaiknya E-learning dimulai terlebih dahulu pada sebuah unit yang kecil dan dievaluasi sepenuhnya terlebih dahulu untuk menjadi model bagi sistem dalam skala yang lebih besar.

3. Mengkomunikasikan dengan Peserta Didik

Menerapkan sebuah sistem baru akan memberikan tingkat keberhasilan lebih baik apabila sasaran dari sistem tersebut memahami dengan baik sistem tersebut. Demikian pula dengan E-learning, apabila peserta didik memahami tentang sistem yang dibangun dan dikembangkan maka mereka dapat turut memberikan bantuan untuk mencapai tujuan E-learning tersebut. Didasari alasan tersebut maka pengembang sistem E-learning seharusnya selalu mengkomunikasikan sistem yang sedang coba dibangun kepada peserta didik.

4. Melakukan Evaluasi secara Kontinyu 
Evaluasi terhadap sistem dan segenap aspeknya perlu dilakukan secara terus menerus untuk menjamin keberhasilan penerapan E-learning. Membandingkan hasil belajar peserta didik dengan pembelajaran secara konvensional dapat memberikan justifikasi apakah sistem E-learning yang dikembangkan memenuhi standar keberhasilan proses pembelajaran atau tidak. 5. Mengembangkan sistem dalam skala lebih besar

Setelah sistem mencapai keberhasilan dalam skala kecil maka selanjutnya adalah mengembangkan sistem dalam skala lebih besar. Menambah jumlah peserta didik, mata pelajaran, model evaluasi dan berbagai aspek pembelajaran lainnya dapat dilakukan dengan mengacu model dari skala yang lebih kecil yang telah dikembangkan sebelumnya.

\section{Contoh-contoh Sukses (Good Case) E-learning untuk Peningkatan Kompetensi Pendidik}

Berikut ini adalah beberapa contoh sukses penerapan E-learning untuk peningkatan kompetensi pendidik di beberapa negara:

1. Online supported distance education for the qualification of teachers of German as a second language (http://www.fif-rlp.de)

Di Jerman, para imigran diwajibkan untuk bisa berbahasa Jerman sebelum mereka mendapatkan status sebagai penduduk Jerman. Kementrian imigrasi menyediakan guru yang umumnya juga adalah mantan imigran. Calon guru yang tidak memiliki latar belakang pendidikan di bidang bahasa Jerman atau pendidikan diwajibkan mengikuti pelatihan terlebih dahulu. Sejak tahun 2005 kementrian imigrasi mencoba meningkatkan fleksibilitas pelatihan dengan menggunakan E-learning melalui program ini. Kesusksesan program yang masih berlanjut hingga saat ini banyak disebabkan oleh pengakuan kementrian imigrasi terhadap hasil pelatihan melalui E-learning yang dianggap setara dengan pelatihan tatap muka.

\section{PrimTICE (http://primtice.education.fr)}

PrimTICE adalah sebuah proyek yang memberikan fasilitasi pada para guru dan pengawas sekolah dasar dan menengah di Prancis untuk bertukar berbagai rencana proses pembelajaran, media belajar, dan pengalaman belajar mengajar. Tersedia basis data yang telah berisi sekitar 1000 rencana proses pembelajaran dan fasilitas virtual classroom. Aspek sukses dari program ini banyak terdapat pada sisi teknologi terbaru di area E-learning semacam Interactive Whiteboard dan Learning Resources Exchange

3. House of Future-School of Future Teacher Training(http://www.millenaris.hu)

Proyek ini berasal dari kebutuhan yang mirip dengan keadaan di Indonesia saat ini. Pemerintah
Hungaria berniat memberikan kesempatan bagi para guru untuk mengikuti pelatihan yang murah, berjenjang, dan diakui secara profesional dengan topik tentang metode pembelajaran modern. Sejak tahun 2007 telah lebih dari 4000 orang guru mengikuti pelatihan dengan E-learning melalui situs ini.

4. Model E-learning untuk PNF (http://bppnfi4.web.id)

Model ini dikembangkan di BPPNFI Regional IV sebagai inovasi bentuk pelatihan bagi pamong belajar di provinsi Jawa Timur (Noerharijanti, 2008). Situs Elearning diujicobakan pada pelatihan yang diikuti 10 orang pamong belajar SKB. Di mana 5 orang mengikuti pelatihan tatap muka sedangkan 5 orang dengan pelatihan melalui E-learning. Dari segi waktu peserta pelatihan tatap muka membutuhkan 30 jam pelatihan (@45 menit) selama 3 hari atau setara dengan 7,5 jam/ hari. Peserta yang datang dari luar kota membutuhkan waktu untuk menginap dan melakukan perjalanan pulang pergi sebanyak 1 kali. Dari ujicoba yang dilakukan peserta pelatihan melalui E-learning rata-rata membutuhkan waktu belajar selama 2 jam sehari dengan waktu pelatihan selama 10 hari. Mereka juga membutuhkan perjalanan pulang pergi sebanyak minimal 1 kali untuk mengikuti ujian akhir. Dari hasil ujian tampak bahwa hasil ujian tulis peserta E-learning mampu mencapai $95 \%$ dari nilai peserta pelatihan tatap muka. Sedangkan hasil ujian praktek mencapai 93\%. Artinya tidak terjadi perbedaan secara signifikan dari kompetensi peserta yang didapat antara pelatihan tatap muka dan pelatihan dengan E-learning. Sedangkan dari segi pembiayaan pelatihan dengan E-learning hanya membutuhkan biaya $57 \%$ dari pelatihan tatap muka dengan menghilangkan biaya akomodasi.

\section{Isu-isu Penting Seputar E-learning}

Selain berbagai kelebihan dan aspek positif yang telah dijabarkan di atas, terdapat pula beberapa hal yang yang memerlukan perhatian khusus sebelum menerapkan E-learning sebagai alternatif pengganti pelatihan tatap muka, yaitu:

\section{Pengakuan Legal Formal}

Banyak keraguan yang menyatakan bahwa hasil pembelajaran dengan E-learning sulit untuk diakui secara legal karena minimnya interaksi langsung antara pendidik dengan peserta didik. Hal ini disebabkan minimnya instrumen evaluasi yang hanya berupa ujian secara online dan sering dianggap kurang valid dalam menilai hasil belajar. Dalam mengatasi hal ini biasanya penyedia layanan E-learning melakukan blended learning yaitu mengkombinasikan pembelajaran konvensional dengan E-learning. Pada pendekatan ini umumnya pembelajaran dilakukan melalui E-learning tetapi setiap jangka waktu tertentu peserta didik 
diharuskan hadir dan saling bertemu dengan pendidik untuk melakukan evaluasi.

2. Aspek Kognitif dan Sosial

Pelatihan dengan e-learning memberikan hasil yang hampir setara dengan pembelajaran tatap muka bahkan dengan efisiensi waktu yang lebih baik dan biaya yang lebih murah. Meskipun demikian banyak aspek kognitif dan sosial yang hilang pada pembelajaran dengan E-learning. Interaksi antara peserta didik dengan instruktur dan sesama peserta didik yang dapat meningkatkan kualitas pembelajaran jauh lebih rendah daripada pembelajaran tatap muka. Walaupun demikian E-learning terbukti dapat menjadi alternatif bagi pelatihan, terutama pelatihan yang para pesertanya memiliki keterbatasan atau kendala jarak, waktu, dan biaya untuk hadir di tempat pelatihan tatap muka dilaksanakan. Dengan menerapkan pelatihan jarak jauh dengan e-learning secara cermat dan tidak menghilangkan aspek sosial bagi para peserta maka pelatihan jenis ini dapat memperluas akses layanan pelatihan bagi para pendidik pendidikan nonformal maupun profesi-profesi lainnya.

3. Motivasi Peserta

Paradigma belajar dengan E-Learning adalah menjadikan peserta didik sebagai active learner. Proses pembelajaran tidak bergantung pada aktivitas pendidik tetapi lebih pada motivasi dan cara belajar peserta didik. Dengan E-learning peserta yang bersemangat dan memiliki motivasi tinggi akan dengan mudah menguasai berbagai kompetensi yang dipelajari tetapi demikian pula sebaliknya bagi peserta yang cenderung malas. Gaya mengajar pendidik yang sering menjadi daya tarik pada suatu proses belajar mengajar tradisional tidak bisa sepenuhnya diandalkan pada E-learning. Kualitas media belajar dan kemampuan berdiskusi secara online dari pendidik berperan jauh lebih penting pada pembelajaran dengan E-learning .

4. Aspek Teknologi

Walaupun teknologi internet di Indonesia saat ini telah berkembang secara pesat tetapi hal ini tidak berlaku secara merata. Banyak daerah yang belum menikmati layanan internet berkecepatan tinggi seperti di kota-kota besar. Untuk persoalan demikian diperlukan media belajar yang dapat digunakan pada komputer stand-alone agar peserta didik tidak perlu setiap waktu mengakses internet untuk melakukan proses pembelajaran.

\section{KESIMPULAN}

Sebagai salah satu bentuk penerapan TIK dalamdunia pendidikan, E-learning menawarkan berbagai kelebihan yang dapat menjadikannya sebagai alternatif pengganti pelatihan tatap muka bagi peningkatan kompetensi PTK PNF. Berbagai kelebihan tersebut antara lain dapat menjadikan peserta pelatihan menjadi seorang active learner yang mandiri dan tidak terlalu bergantung kepada instruktur /narasumber pelatihan. E-learning juga memperluas akses layanan dan menekan biaya pelatihan yang selama ini sangat mahal.

Walaupun demikian dari sisi kualitas proses belajar mengajar, E-learning memiliki kelemahan pada aspek sosial dan kognitif yang diakibatkan minimnya interaksi langsung antara peserta didik dengan rekanrekannya maupun dengan instruktur. Dari segi evaluasi pun tidak dapat menjamin kualitas hasil dari E-learning akan setara dengan pelatihan tradisional.

Salah satu pendekatan terbaik untuk menerapkan E-learning bagi pelatihan PTK PNF adalah dengan blended learning. Di mana selain pembelajaran dengan E-learning diperlukan pertemuan dan evaluasi dengan tatap muka. Pertemuan ini cukup dilakukan secara singkat agar tetap dapat menekan biaya akomodasi dari pelatihan tradisional.

\section{DAFTAR PUSTAKA}

Adri, M. (2008). Pengembangan model belajar jarak jauh FT UNP dengan P4TK Medan dalam rangka perluasan kesempatan belajar. Diakses tanggal 20 Mei 2008 dari Portal www.ilmukomputer.com

Henderson, A. J. (2003). The e-learning question and answer book. New York, USA: American ManagementAssociation
Mayer, R. E. (2001). Multimedia Learning. USA: Cambride University Press.

Noerharijanti, D.A. (2008). Laporan pengembangan model e-learning untuk PNF. Surabaya: BPPNFI Regional IV

Nugraha, W. (2007). E-learning vs i-learning, Penyempitan makna e-learning dan penggunaan 
Pemanfaatan E-Learning sebagai Alternatif...

istilah internet-learning. Diakses tanggal $20 \mathrm{Mei}$ 2008 dari portal www.ilmukomputer.com

Wahono, R.S. (2003). Strategi baru pengelolaan situs e-learning gratis. Diakses tanggal 1 Juni 2008 dari http://www.ilmukomputer.com

Wahono, R.S. (2007). Pengantar e-Learning dan pengembangannya. Diakses tanggal 1 Juni 2008 dari Portal www.ilmukomputer.com 